\title{
The Global Compact. Corporate Leadership in the World Economy
}

\author{
Kofi Annan*
}

\begin{abstract}
United Nations Secretary-General Kofi Annan first proposed the Global Compact in an address to The World Economic Forum on the $31^{\text {st }}$ January 1999.

The Global Compact's operational phase was launched at UN Headquarters in New York on the $26^{\text {th }}$ July 2000. The Secretary-General challenged business leaders to join an international initiative - the Global Compact - that would bring companies together with UN agencies, labour and civil society to support nine principles in the areas of human rights, labour and the environment.

The Global Compact is a voluntary corporate citizenship initiative. The Global Compact is a network. The Global Compact involves all the relevant social actors: governments, companies, civil society organizations, and The United Nations.
\end{abstract}

Keywords: The Global Compact; The Global Compact Network; World Economy; Global Markets; Corporate Leadership

"Let us choose to unite the powers of markets with the authority of universal principles"

\section{Overview}

United Nations Secretary-General Kofi Annan first proposed the Global Compact in an address to The World Economic Forum on 31 January 1999. The Global Compact's operational phase was launched at UN Headquarters in New York on 26 July 2000. The Secretary-General challenged business leaders to join an international initiative - the Global Compact - that would bring companies together with UN agencies, labour and civil society to support nine principles in the areas of human rights, labour and the environment.

Through the power of collective action, the Global Compact seeks to advance responsible corporate citizenship so that business can be part of the solution to the challenges of globalisation. In this way, the private sector - in partnership with other social actors - can help realize the Secretary-General's vision: a more sustainable and inclusive global economy.

Today, hundreds of companies from all regions of the world, international labour and civil society organizations are engaged in the Global Compact. The Global

*United Nations Secretary General (globalcompact@un.org)

Annan Kofi, The Global Compact. Corporate Leadership in the World Economy, Symphonya. Emerging Issues in Management (symphonya.unimib.it), n. 2, 2002, pp. 7-10 
Compact is a direct initiative of the Secretary-General; its staff and operations are lean and flexible.

The Global Compact is a voluntary corporate citizenship initiative with two objectives:

- making the Global Compact and its principles part of business strategy and operations;

- facilitating cooperation among key stakeholders and promoting partnerships in support of U.N. goals.

To achieve these objectives, the Global Compact offers facilitation and engagement through several mechanisms: Policy Dialogues, Learning, Local Structures and Projects.

The Global Compact is not a regulatory instrument - it does not "police", enforce or measure the behavior or actions of companies. Rather, the Global Compact relies on public accountability, transparency and the enlightened self-interest of companies, labour and civil society to initiate and share substantive action in pursuing the principles upon which the Global Compact is based.

The Global Compact is a network. At its core are the Global Compact Office and four UN agencies: Office of the High Commissioner for Human Rights; United Nations Environment Programme; International Labour Organization; United Nations Development Programme. The Global Compact involves all the relevant social actors: governments, who defined the principles on which the initiative is based; companies, whose actions it seeks to influence; labour, in whose hands the concrete process of global production takes place; civil society organizations, representing the wider community of stakeholders; and The United Nations, the world's only truly global political forum, as an authoritative convener and facilitator.

\section{Why Participate}

There are numerous benefits to participating in the Global Compact. These include:

- producing practical solutions to contemporary problems related to globalisation, sustainable development and corporate responsibility in a multi-stakeholder context;

- rallying around universal principles and responsible corporate citizenship to make the global economy more sustainable and inclusive;

- leveraging the UN's global reach and convening power with governments, business, civil society and other stakeholders;

- sharing good practices and learnings.

- accessing the UN's broad knowledge in development issues and its practical reach worldwide.

\section{The Nine Principles}

The Global Compact's nine principles in the areas of human rights, labour and the environment enjoy universal consensus being derived from:

- the Universal Declaration of Human Rights; 
- the International Labour Organizations Declaration on Fundamental Principles and Rights at Work;

- the Rio Declaration on Environment and Development;

The nine principles are:

Human Rights

Principle 1: Businesses should support and respect the protection of internationally proclaimed human rights within their sphere of influence; and

Principle 2: make sure that they are not complicit in human rights abuses.

\section{Labour Standards}

Principle 3: Businesses should uphold the freedom of association and the effective recognition of the right to collective bargaining;

Principle 4: the elimination of all forms of forced and compulsory labour;

Principle 5: the effective abolition of child labour; and

Principle 6: eliminate discrimination in respect of employment and occupation.

\section{Environment}

Principle 7: Businesses should support a precautionary approach to environmental challenges;

Principle 8: undertake initiatives to promote greater environmental responsibility; and

Principle 9: encourage the development and diffusion of environmentally friendly technologies.

\section{How to Participate in the Global Compact}

As a voluntary initiative, the Global Compact seeks wide participation from a diverse group of businesses and other organizations. To participate in the Global Compact, a company:

- sends a letter from the Chief Executive Officer (and, where possible, endorsed by the board) to Secretary-General Kofi Annan expressing support for the Global Compact and its principles (www.unglobalcompact.org);

- sets in motion changes to business operations so that the Global Compact and its principles become part of strategy, culture and day-to-day operations (described below);

- is expected to publicly advocate the Global Compact and its principles via communications vehicles such as press releases, speeches, etc.;

- is expected to publish in its annual financial report or similar corporate report (e.g. sustainability report) a description of the ways in which it is supporting the Global Compact and its nine principles.

In terms of the practical ways in which companies pursue the principles, the Global Compact offers engagement opportunities to all participants through the following:

Global Policy Dialogues. Each year, the Global Compact convenes a series of action-oriented meetings that focus on specific issues related to globalisation and corporate citizenship. The meetings bring businesses together with UN agencies, 
labour, non-governmental organizations and other groups to produce solutions to contemporary problems. Issues addressed have included "The Role of the Private Sector in Zones of Conflict"; and "Business and Sustainable Development".

Local Structures. The Global Compact encourages the creation of local structures and networks at the country or regional level. Such networks are designed to support: the implementation of the nine principles; mutual learning and information exchange; the convening of local/regional dialogues on globalisation issues; partnership projects; and the recruiting of additional companies. The Global Compact Office and UNDP facilitate and support the process leading to the formation of these local structures.

Learning. Companies are invited to share examples of corporate practices on the Global Compact web portal. In addition, participants are encouraged to develop indepth case studies and analyses, and to use these for Learning activities in the corporate and academic worlds. Local, regional and international Learning events support the sharing of knowledge.

Partnership Projects. The Global Compact encourages companies to participate in partnership projects with UN agencies and civil-society organizations that are aligned with UN development goals.

\section{The Global Compact Network}

The Global Compact is a network-based initiative. At its core are the Global Compact Office and four UN agencies. The Global Compact involves all relevant social actors: governments, who define the principles on which the initiative is based; companies, whose actions it seeks to influence; labour, in whose hands the concrete process of global production takes place; civil society organizations, representing the wider community of stakeholders; and the United Nations, the world's only truly global political forum, as an authoritative convener and facilitator.

Below is a schematic diagram that illustrates this network approach.

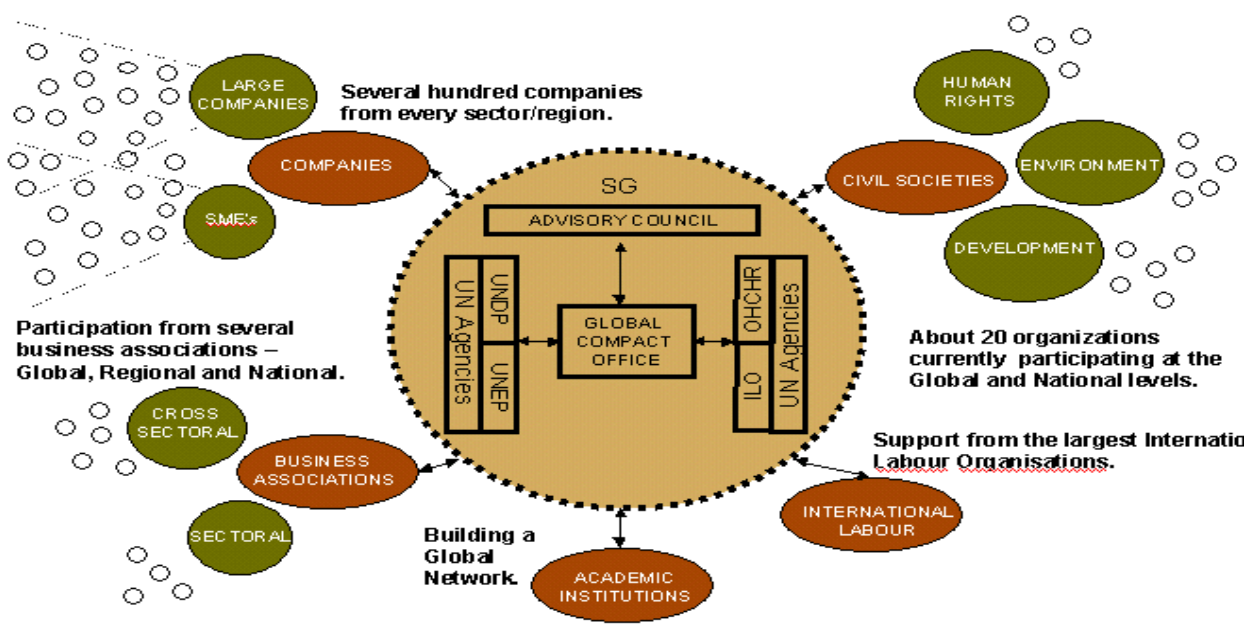

GOVERNMENTS FROM NORTH\&SOUTH SUPPORTIVE 